\title{
O Aspecto Pulsional do Fanatismo Religioso
}

\section{The Pulsional Aspect of Religious Fanaticism}

\author{
Thiago Araújo Oliveira' (orcid.org/0000-0002-6105-7516) \\ Ilka Franco Ferrari2 (orcid.org/0000-0002-6367-3136)
}

\begin{abstract}
Resumo
Elaborado a partir de pesquisa bibliográfica, este texto trata do fanatismo religioso, abordando-o a partir de estudiosos do assunto e de alguns pressupostos da teoria freudiana a respeito da religião, dos fenômenos grupais e do dinamismo pulsional no indivíduo e na coletividade. Tem como objetivo ponderar e refletir sobre a intransigência, a intolerância e a violência que caracterizam o comportamento de grupos reunidos e movidos por suas crenças. Chegase à compreensão de que essas atitudes são formas de expressão da pulsão de morte que, presente nas religiões enquanto construções humanas, imprime também nelas a marca da ambivalência própria do humano.
\end{abstract}

Palavras-chave: Fanatismo. Pulsão de morte. Religião. Freud.

\begin{abstract}
This text, elaborated from bibliographical research, deals with religious fanaticism, approaching it from scholars of the subject and some assumptions of Freudian theory regarding religion, group phenomena and pulsional dynamism in the individual and in the collective. It aims to ponder and reflect on the intransigence, intolerance and violence that characterize the behavior of groups gathered and moved by their beliefs. It reaches the understanding that these attitudes are forms of expression of the death instinct that, present in religions as human constructions, also imprints on them the mark of ambivalence proper to the human.
\end{abstract}

Keywords: Fanaticism. Death instinct. Religion. Freud.

\footnotetext{
1 Pontifícia Universidade Católica de Minas Gerais, Belo Horizonte, Brasil. E-mail: thiagoaraujool@yahoo.com.br. 2 Pontifícia Universidade Católica de Minas Gerais, Belo Horizonte, Brasil. E-mail: francoferrari@terra.com.br.
} 


\section{Introdução}

As religiões, como todas as construções humanas, são marcadas pelas ambiguidades e contradições próprias do ser humano. Por esse motivo, a 'inclinação humana para a 'ruindade', a agressividade e a destrutividade, e também para a crueldade" (Freud, 1930/2006, p. 142) pode estar imiscuída com os mais nobres ideais da fé.

Este texto se constrói baseando-se nas formalizações de Freud sobre a religião, os fenômenos de grupo e o caráter pulsional do humano. Esses aportes teóricos são utilizados para pensar sobre o fanatismo religioso, no qual se revela a atuação da pulsão de morte que habita todo homem, inclusive o crente.

\section{A Violência na Origem da Religião}

Para Freud (1913/2006), o Complexo de Édipo está no início da civilização e do sentimento religioso. Para sustentar essa ideia, em Totem e tabu ele lançou mão do mito da horda primitiva e da morte do chefe da horda, o pai, que fora executado e devorado pelos filhos, aos quais subjugava, castigava, impedia de se apropriarem das fêmeas e bania da horda. Depois do parricídio consumado, os irmãos vitoriosos retornaram à horda e, para viverem em paz e impedir que algum deles assumisse o lugar do pai, instituíram a exogamia. Dessa forma, o poder paterno foi anulado e as famílias se organizaram em matriarcado.

O sentimento ambivalente dos filhos para com o pai, porém, persistia. Se o odiavam porque ele "representava um obstáculo tão formidável ao seu anseio de poder e aos desejos sexuais", por outro lado, "amavam-no e admiravam-no também." (Freud, 1913/2006, p. 146). Se o ódio que sentiam por ele proporcionou a coragem de matá-lo, o amor proporcionou a saudade, o remorso e a culpa. Por isso, trataram de providenciar um substituto para o pai: um totem que, normalmente, era um animal.

Anualmente, os machos do clã se reuniam para uma refeição sagrada. Nessa ocasião, o totem - que antes era adorado e protegido - era brutalmente morto, despedaçado e tinha sua carne devorada pelos participantes da cerimônia. Todos os machos eram obrigados a participar desse repasto ritual, por meio do qual eles repetiam o ato violento do parricídio, praticado no passado. Nesse evento mítico, Freud $(1938 / 2006)$ situa a origem das instituições sociais, da religião e da moralidade.

Ao apresentar essa refeição ritual totêmica como "uma primeira tentativa de religião”, Freud (1913/2006, p. 147) vincula o sentimento religioso, desde sua origem, à violência e à culpa pela morte de um pai. Para ele, a sociedade dos irmãos baseava-se na "cumplicidade do crime comum", enquanto a religião baseava-se "no sentimento de culpa e no remorso a ele ligado" (Freud, 1913/2006, p. 149). Suas formalizações chegam ao ponto de dizer que as religiões surgidas, ao longo da história, são tentativas de solucionar o mesmo problema, variando apenas conforme o momento em que surgiram e conforme os métodos que adotam. Nesse sentido, vale ressaltar que, naquela primitiva configuração 
religiosa, há muita semelhança com o rito da comunhão eucarística cristã, pelo qual os fiéis também fazem memória da morte violenta de Cristo, comendo o pão e bebendo o vinho, como sacramentos de seu corpo e sangue (Freud, 1938/2006).

Ao consumir a carne do pai, os filhos "realizavam a identificação com ele, cada um deles adquirindo uma parte de sua força" (Freud, 1913/2006, p. 145) e, desse modo, assumiam também a marca da violência paterna. O pai, de fato, constituía um modelo temido e invejado pelos filhos, que também lhe devotavam um religioso respeito.

Os meios religiosos atuais não são isentos desses percalços e vê-se que, neles, podem existir filhos (fiéis) violentos que, em nome da devoção a um deus-pai único, absoluto e onipotente, tornam-se também intransigentes, impositivos e intolerantes. É o que se pode observar, por exemplo, no fanatismo de alguns grupos religiosos.

Bobbio, Matteucci e Pasquino (1998, p. 464) definem o fanatismo como "cega obediência a uma ideia, servida com zelo obstinado, até exercer uma violência para obrigar outros a segui-la e punir quem não está disposto a abraçá-la". Segundo esses mesmos autores, as consequências da mentalidade fanática são a hostilidade a ideias alheias e o insensato proselitismo que lança mão, até mesmo, de atos cruéis. Embora o fanatismo seja perceptível em alguns ambientes religiosos, pode, no entanto, estar associado a variadas ideias e não, necessariamente, apenas à religião. Há, por exemplo, fanatismo na política, no esporte, na arte e nos meios acadêmicos.
No âmbito específico da religião, o fanatismo consiste num empenho exasperado do crente em defender suas posições doutrinárias e convencer os outros a abraçar a mesma fé. Quanto mais essa fé se sente questionada e ameaçada, maior o empenho em defendê-la e mostrar seu valor e eficácia. Nesse sentido, pode-se perceber que o fanatismo religioso é uma tentativa de fazer valer, a todo custo, uma crença que, no fundo, percebe-se frágil ou abalada em seus fundamentos. Quando a religião é questionada, seus mais zelosos defensores sentem-se eles mesmos ameaçados e lesados (Oro, 1996). Assim, a reação de contra-ataque nem sempre é isenta de certa forma de violência. Por esse motivo, percebe-se que, ao longo da história das religiões e em ambientes de forte imposição religiosa, a violência sempre foi aliada do sagrado.

\section{A Imposição do Único e a Negação da Diversidade}

Em Moisés e o monoteísmo, Freud (1938/2006) analisou como o antigo pai da horda primeva retornou por intermédio das religiões monoteístas, que sucederam o politeísmo. Ele pensou esse "retorno de um deus-pai único de poder ilimitado" (Freud, 1938/2006, p. 98) também por meio do desenvolvimento do Complexo de Édipo. Para esse mesmo Complexo, convergem, segundo Freud, os inícios da religião, da moral, da sociedade e da arte. Isso condiz com sua convicção de que "os problemas da psicologia social se mostrem solúveis com base num único ponto concreto: a relação do homem com o pai." (Freud, 1913/2006, p. 158). Com relação a 
isso, Neto e Rosário (2016) ressaltam que as pesquisas psicanalíticas fizeram Freud perceber o Complexo de Édipo como o núcleo de todas as neuroses, entre as quais ele inseriu a religião como uma neurose obsessiva universal da humanidade.

Freud (1938/2006) ainda acentua, em Moisés e o monoteísmo, que a necessidade de um pai protetor leva o homem a pensar que "não pode passar sem o apoio de seu deus" (Freud, 1938/2006, p.142). Por esse motivo, depois que os filhos parricidas criaram um substituto para o pai, por meio de um totem, esse primeiro substituto deu lugar a um deus e, desse modo, o pai reconquistou a aparência humana. A criação de um deus com traços humanos ocorreu porque, no decurso do tempo, houve uma mudança fundamental na relação do homem com o pai, transformando o azedume que sentiam por ele em saudade. Isso os levou a criarem um ideal que corporificava o poder ilimitado de que o pai primitivo era detentor e, ao mesmo tempo, surgiu uma nova disposição de submeter-se a ele.

Por outro lado, com as mudanças culturais que foram se desencadeando, a igualdade democrática original que predominava entre os membros do clã, depois da morte do pai, tornou-se insustentável. Com isso, foi se desenvolvendo uma inclinação a retomar a antiga forma de vida sob a tutela paterna. Essa inclinação, juntamente com a veneração que se tinha por determinados seres humanos, propiciou então reviver o antigo ideal (Freud, 1913/2006).

O pai assassinado, elevado agora à condição de um deus, passou a ser reverenciado como ascendente comum de todos e a culpa por sua morte foi então expiada de maneira muito mais eficaz do que o fora anteriormente, por intermédio do pacto com um totem. Ele ganhou novos atributos e engrandecimentos com o monoteísmo, que se impôs como religião dominante. As instituições do clã fraterno, do matriarcado, da exogamia e do totemismo serviram ao desenvolvimento dessa nova concepção de deus, considerada por Freud $(1938 / 2006$, p. 146) como um "retorno do reprimido". ${ }^{3}$ Ele adverte, no entanto, que, nesse caso, o termo reprimido é empregado no sentido de algo que, na vida de um povo, é passado, perdido de vista, relegado e, de alguma forma, retorna. Esse retorno seguiu as mudanças nas condições de vida da humanidade, por isso realizou-se de modo lento e não espontâneo.

Segundo a hipótese de Freud (1938/2006), a ideia de um deus supremo começou a se impor a partir do momento em que várias tribos e povos começaram a se associar em unidades maiores. Cada tribo ou povo trazia suas divindades que começavam a ser ajuntadas e organizadas em famílias e hierarquias, tal como acontecia com as pessoas. Uma dessas divindades passava a ser considerada como a maior entre as outras. O passo seguinte foi na direção de prestar homenagem somente a esse deus supremo e considerá-lo único, não tolerando outros deuses, além do soberano e universal.

Com o respeito prestado a um só deus, foi-lhe atribuído também todo o poder, em uma

\footnotetext{
3 Em algumas traduções dos textos freudianos, a palavra repressão, da qual deriva reprimido, é utilizada para traduzir o termo alemão Verdräng. Tradutores atuais, porém, preferem utilizar o termo recalque, do qual também deriva recalcado.
} 
espécie de ressurgimento e reabilitação do antigo pai da hora primitiva, que demonstrou, mais uma vez, seu lado despótico, possessivo e egoísta (Neto \& Rosário, 2006).

O teólogo Ribeiro (2011) acentua o fato de que o monoteísmo é uma forma de negação da alteridade e que há teorias que apontam as religiões monoteístas como as mais vinculadas ao uso da violência e as que mais contribuem para seu aumento na vida social. Isso condiz com a observação de Bonome (2009), segundo a qual é no seio das religiões monoteístas que se desenvolve o fundamentalismo religioso, imbuído pelo ideal de defender os valores religiosos, a única fé, o único deus, a única verdade e o único livro sagrado, por meio de uma luta acirrada contra tudo e contra todos que divirjam dessa unidade. Se no politeísmo há lugar para uma diversidade de entidades divinas, no monoteísmo há uma tendência a esmagar e reprimir as diferenças, com a imposição de uma fé e uma verdade que se tornam tão absolutas quanto a religião. Nesse sentido, num texto bíblico do Antigo Testamento, há uma categórica afirmação do único Deus que até mesmo sente ciúmes, rejeitando qualquer outro que seja colocado a seu lado:

Não terás outros deuses diante de mim [...]. Não te prosternarás diante desses deuses e não os servirás, por que eu sou o Senhor, teu Deus, um Deus ciumento, visitando a iniquidade dos pais nos filhos [...] se eles me odeiam, mas provando a minha fidelidade a milhares de gerações - se eles me amam e guardam meus mandamentos. (Êxodo 20, 3. 5-6)

O apóstolo Paulo também ressalta, no Novo Testamento, o ideal cristão monoteísta, afirmando que "Há um só corpo e um só Espírito, do mesmo modo que a vossa vocação vos chamou a uma só esperança; um só Senhor, uma só fé, um só batismo; um só Deus e Pai de todos, que reina sobre todos, age por meio de todos e permanece em todos" (Efésios 4, 4-6).

Ribeiro (2001) lembra que, para alguns críticos da religião, o cristianismo seria a face mais violenta dos três monoteísmos. Basta olhar para a história da civilização ocidental, profundamente influenciada pelo cristianismo, para se perceber o quanto se faz marcante uma cultura de violência, caracterizada pelo fanatismo e pela intolerância. Segundo o autor, o cristianismo pode apresentar uma imagem de um Deus Pai sádico, que só tem sua ira aplacada e seu senso de justiça satisfeito pelo sacrifício de uma vítima inocente: o próprio filho. Embora no cristianismo haja outras formas de abordar o tema da morte redentora de Cristo, a ideia de sua morte vicária - pela qual ele oferece a Deus Pai o sacrifício da própria vida para ganhar o perdão para os pecadores - não deixa de ter um grande peso no imaginário religioso ocidental. Um Deus violento, que só se contenta com o sangue de um inocente, reflete-se numa religião cujos membros também podem assumir atitudes violentas e, por isso, fanáticas.

Para Freud (1938/2006), no surgimento do monoteísmo, o efeito de ter reencontrado a figura paterna, pela qual tanto se ansiou, foi esmagador. Novamente passou-se a devotar toda admiração, respeito, temor e gratidão pelo pai, por se ter encontrado graças diante dele. Esses sentimentos, conforme ele lembra, são marcantes no monoteísmo fundado por Moisés, o judaísmo. A concepção de deus que se solidificou na religião mosaica acabaria tendo 
influência decisiva para outras formas posteriores de monoteísmo, como o cristianismo e o islamismo.

No pensamento freudiano, a irresistibilidade do deus único e soberano e a necessidade de se submeter à vontade dele remetem à situação de desamparo vivida pelo filho do chefe da antiga horda, depois que este fora morto. Os impulsos emocionais que o filho sentia pelo pai foram revividos, por intermédio do enlevo da devoção ao deus único e universal, adorado no monoteísmo.

\section{Amor e Ódio na Religião}

Enriquez (2001) propõe que a religião constitui o ser humano como ser heterônimo, ou seja, como alguém que depende de uma realidade sagrada e transcendente. A essa realidade sobrenatural deve-se render homenagens pelos benefícios recebidos, sujeitarse e sentir-se sempre em dívida para com ela. Caso não se enquadre nessa atitude devota em relação à entidade sobrenatural, o indivíduo fica sujeito à exclusão da comunidade. Com isso, a religião constitui o ser-junto, ou seja, cria vínculos entre as pessoas, ao vinculá-las ao próprio ser numinoso. $\mathrm{Na}$ raiz latina da palavra religião, já se encontra a ideia de vínculo, pois o verbo religare (ligar), do qual se origina, significa justamente criar laços, atar ou ligar: ligar os homens ao divino e ligar os homens entre si. Dessa forma, ao ligar os homens entre si e a algum poder celestial, a religião revela a pretensão de salvar as pessoas da solidão, da angústia diante do caos da existência e da interrogação pelo sentido da vida; interrogação que pode levar o ser humano a se defrontar com o aspecto arbitrário de sua presença no mundo.

A partir do texto de Freud (1913/2006), fica evidente que, também para ele, a religião faz parte do processo de associação entre os indivíduos na sociedade, sendo ela própria um sistema social. Em Moisés e o monoteísmo, Freud (1938/2006, p. 134) mais uma vez acentuou que "O totemismo, a forma mais primitiva de religião que identificamos, traz consigo, como constituintes indispensáveis de seu sistema, uma série de ordens e proibições [...]. Nesses regulamentos, devem ser vistos os primórdios de uma ordem moral e social". $\mathrm{Na}$ linha do pensamento freudiano, portanto, o corpo social e as diretrizes normativas desse corpo não surgem sem a religião, que sempre esteve presente nas diversas sociedades, manifestandose de inúmeras formas, por exemplo, no culto aos ancestrais, na instituição de totens, na criação de deuses, de mitos, na veneração de determinadas personalidades heroicas e sua deificação. Mas, se a religião, desde sua origem, constitui um aspecto inerente à vida social, isso não significa que, necessariamente, ela deve assumir formas fanáticas ou dominadoras.

Em sua consideração sobre as religiões nascidas no Oriente-Próximo, Enriquez (2001) as vê como uma mensagem sobre a transcendência e sobre as relações que seus adeptos, reunidos em comunidade, devem estabelecer entre si e com o sagrado. Fora dessas relações, os indivíduos podem se tornar alvo de hostilidade e agressões, das mais variadas formas. A mensagem transcendente, nessas configurações religiosas, é anunciada por um líder, ao qual se associa um número de discípulos, formando uma seita. Quando a seita 
consegue se difundir e se estabelecer em instituições sólidas, com seus templos e ritos, isso indica que, enquanto minoria ativa, ela conseguiu se desenvolver e ganhar força. Mas a seita só consegue esse desenvolvimento se lançar mão de sua força de convicção, se assumir um traço absolutista, se apelar para o sacrifício de seus mártires e se impuser sua intolerante visão de mundo sobre as outras visões, formulando dogmas e rituais violentos que expressam seu poder conquistador, provocando a submissão e o respeito de povos inteiros. Um grupo minoritário, portanto, que desejasse continuar minoritário e não assumisse uma postura de intolerância para com os outros, nunca poderia se tornar uma religião propriamente dita.

A religião, para Enriquez (2001), existe porque a comunidade de crentes conseguiu recalcar alguns desejos e fantasias, substituindoos por outros que se tornaram ideais religiosos. Em Freud (1938/2006), pode-se encontrar embasamento para essa ideia, quando ele propõe que, no sistema religioso totêmico, os desejos agressivos e sexuais recalcados foram substituídos por regulamentos comunitários, que propunham o respeito à vida alheia, a exogamia e a concessão de direitos iguais entre os irmãos.

Quanto ao monoteísmo mosaico, Freud (1938/2006, p. 133) também o considera como uma "religião de renúncias instintuais". 4 Também nesse caso, os desejos recalcados foram substituídos por ideais religiosos, defendidos com ardor pelos profetas que "nunca se cansaram de asseverar que Deus nada exige de

\footnotetext{
4 Tradutores atuais da obra freudiana preferem a palavra pulsão a instinto, para traduzirem o termo alemão Trieb. Por isso, a palavra instintual pode ser também compreendida como pulsional.
}

seu povo senão uma conduta de vida justa e virtuosa, isto é, abstenção de toda satisfação instintual, que ainda é condenada como impura por nossa mortalidade atual" (Freud, 1938/2006, p. 133). Foi essa renúncia pulsional, preconizada pela religião da crença em um só deus, que teria assegurado a vida em comunidade.

Com relação às intransigentes restrições pulsionais impostas pelos monoteísmos judaico, cristão e islâmico, Onfray (2007, p. 52) considera que, nessas três religiões, o culto ao deus único é animado por "uma mesma pulsão de morte genealógica”. Nelas, faz-se presente uma série de desprezos comuns:

[...] ódio da razão e da inteligência; ódio da liberdade; ódio de todos os livros em nome de um único; ódio da vida; ódio da sexualidade; das mulheres e do prazer; ódio do feminino; ódio do corpo, dos desejos, das pulsões. [...] Equivale a dizer a vida crucificada e o nada celebrado. (Onfray, 2007, p. 52)

Conforme também as considerações de Enriquez (2001, p. 79), “toda religião se alimenta da idealização e do ódio contra o outro”. Por isso, para esse autor, a religião também existe porque conseguiu estipular os inimigos a serem recrutados pela conversão ou perseguidos, excluídos e destruídos. Dessa forma, se a religião pode construir uma cultura, solidificar sua identidade e associar as pessoas em um nós sustentado por laços de fraternidade, essa união continua à medida que o ódio inconsciente de seus integrantes - ódio subjacente às relações humanas devido à sua ambivalência pulsional direciona-se para o exterior do grupo, sendo projetado para os inimigos ideais ou reais. Esse pensamento de Enriquez condiz com o modo de 
Freud (1930) conceber o processo de constituição e dissolução de grupos, a partir do dualismo entre pulsão de vida e pulsão de morte.

Em Psicologia de grupo e análise do ego, Freud (1921/2006, p. 110) diz que as provas da Psicanálise demonstram que, nas relações interpessoais que perduram por certo tempo, há "um sedimento de sentimentos de aversão e hostilidade, o qual só escapa à percepção em consequência da repressão". Quando se forma um grupo, no entanto, a mútua intolerância entre seus componentes se enfraquece, de modo temporário ou permanente: “Os indivíduos do grupo comportam-se como se fossem uniformes, toleram as peculiaridades de seus outros membros, igualam-se a eles e não sentem aversão por eles" (Freud, 1921/2006, p. 113). Isso proporciona uma limitação do narcisismo dos componentes do grupo, por meio do laço libidinal com outras pessoas, o qual pode levar o egoísmo constitutivo dos indivíduos a se transformar em altruísmo. É sob a ação de Eros que esse laço de amor se estabelece no grupo, embora possa permanecer restrito dentro dele.

Por outro lado, o sentimento de hostilidade, inerente às relações intersubjetivas, há que se direcionar, de alguma forma, para o exterior da formação grupal. Essa hostilidade, que é expressão da pulsão de morte, encontrará um escoadouro pela ação de um ou vários inimigos comuns do grupo. $\mathrm{Na}$ religião, essa estratégia para a pulsão de morte se torna manifesta pelo fato de que os grupos religiosos não existem sem a hostilização por um inimigo, seja real ou imaginário, localizado no mundo concreto ou no campo do espiritual. No cristianismo, por exemplo, os fiéis estão vinculados entre si por um duplo laço de amor: o laço comum com um líder supremo, que é Cristo, e o laço de fraternidade com os demais cristãos, contudo,

[...] mesmo durante o reinado de Cristo, aqueles que não pertencem à comunidade de crentes, que não o amam e a quem ele não ama, permanecem fora de tal laço. Desse modo, uma religião, mesmo que se chame a si mesma de religião do amor, tem de ser dura e inclemente para com aqueles que a ela não pertencem. (Freud, 1921/2006, p. 110)

Ao se referir ao momento histórico em que estava vivendo, Freud (1921/2006) salientou que se a crueldade e a violência, em nome da crença, estavam menos expressivas que no passado, isso não significava que tivesse acontecido uma suavização nos costumes humanos. Ele esclarece ainda que, na verdade, foi o enfraquecimento dos sentimentos religiosos, naquele momento, e dos laços libidinais decorrentes deles que propiciou maior discrição da brutalidade sanguinária por motivações religiosas. Mas, se outras formações grupais tomassem o lugar das religiosas, a mesma hostilidade para com os profanos se faria novamente presente, como nos tempos das guerras de religião. As divergências de opinião científica, por exemplo, poderiam atingir um significado semelhante ao religioso e, nos círculos de estudiosos, manifestar-se-ia a hostilidade para com as diferentes opiniões ou teorias.

Em suas considerações sobre os três grandes monoteísmos, Onfray (2007) ressalta que essas religiões têm a pulsão de morte como combustível que as alimenta. Quando essa pulsão se direciona para o interior do segmento 
religioso, surgem as patologias de autodestruição, como se pode perceber, por exemplo, na história dos cismas, nas disputas pelo poder dentro das instituições e no desprezo pela corporeidade e liberdade humana. Em suas pretensões, a religião do Deus único “[...] trabalha pelo ódio a si mesmo, pelo desprezo do próprio corpo, pelo descrédito da inteligência, pela desconsideração da carne, pela valorização de tudo o que nega a subjetividade desenvolvida [...]" (Onfray, 2007, p. 52).

Numa perspectiva que reflete o pensamento freudiano, Onfray (2007) ainda considera que quando a pulsão de morte se volta para o exterior do movimento religioso surgem as agressões, a violência, os crimes, os assassínios e as lutas ideológicas; fenômenos esses tão presentes em alguns movimentos religiosos fanáticos. Nas palavras do autor, a pulsão de morte “[...] projetada contra o outro, fomenta o desprezo, a maldade e a intolerância, que produzem os racismos, a xenofobia, o colonialismo, as guerras, a injustiça social. Basta observar a história para constatar a miséria e os rios de sangue derramados em nome do Deus único [...]" (Onfray, 2007, p. 52).

Essa violência como externalização da pulsão de morte, partindo do movimento religioso, remete aos sintomas e afetos violentos, considerados por Neto e Rosário (2006) como manifestações dos desejos destrutivos e sexuais que foram recalcados, mas que, no inconsciente, continuam operantes e buscando novas formas de se expressarem.

Essa forma de apresentar a religião como portadora de uma disposição para o ódio e para a violência pode chocar com a concepção corrente de que ela é a promotora do amor entre os seres humanos, já que inspirada, sobretudo, no ideal do mútuo amor. No cristianismo, por exemplo, esse ideal é expresso na sentença amaivos uns aos outros. Ao comentar sobre esse ideal cristão, Freud (1930/2006, p. 114) ressalta que se trata de uma "exigência, conhecida em todo o mundo" e que, além disso, "é, indubitavelmente, mais antiga que o cristianismo, que a apresenta como sua reivindicação mais gloriosa". Considera também que esse mandamento pode muito bem ser vivido entre os cristãos, correligionários, mas não em relação a quem professa uma fé diferente ou não professa fé alguma, direcionando para estes toda forma de intolerância. Enriquez (2001), nesse sentido, também defende que as multidões só se aderem a uma religião - sobretudo se ela estiver se formando ou se tiver pretensões de se estabelecer duradouramente - quando ela se apresenta como intolerante, apelando para o sacrifício e para destruição. Foi desse modo, por exemplo, que as religiões monoteístas conseguiram se impor, recrutando adeptos e, em muitas situações, incitando-os ao fanatismo.

Nessa postura fanática, chega-se até mesmo a morrer por certezas de fé, que são preferíveis às dúvidas, pois estas propiciam a angústia das interrogações e do confronto com a imprevisibilidade da vida. Por isso, o fanatismo revela uma necessidade de referências duras para viver, pois há pessoas que talvez sejam menos aptas para agir de maneira democrática e para confrontar-se com a própria solidão e com os limites da existência (Enriquez, 2001).

Nesse contexto de imposição religiosa, a pulsão de morte ganha enorme espaço para sua atuação. Eliminar os pecadores e o pecado que disseminam, eis o alvo da pulsão de morte em 
sua busca de pureza (Mellor, 2004). Há exemplo disso na história do catolicismo, quando a caça aos hereges tomou grande parte dos esforços dos mais devotados homens da religião, que se puseram a serviço da fé nos tribunais da inquisição e nas cruzadas. $\mathrm{O}$ islamismo, em suas formas radicais, também pôde se expandir graças ao dispositivo da guerra santa conquistadora, que lhe possibilitou varrer o paganismo das várias regiões a que chegou. Nos dias atuais, a fúria destruidora da pulsão de morte, partindo do campo religioso, brada seus protestos contra setores seculares e liberais da sociedade e se manifesta no ardor pela defesa de uma moral religiosa tradicional, confrontando-se com outras visões antropológicas e cosmológicas dissonantes.

Há que se ressaltar, no entanto, que religião e fanatismo religioso não devem ser confundidos. A passagem da religião ao fanatismo é uma possibilidade e pode ser previsível, mas não é uma passagem imediata, constante e necessária (Enriquez, 2001). Certas condições podem possibilitar que a religião tome o caminho da intolerância.

\section{A Atual Busca por uma Religião Absolutista}

No contexto da hipermodernidade, tal como é denominada a atualidade pelo filósofo francês Gilles Lipovetsky, constatam-se mudanças socioculturais que acontecem num ritmo frenético. Em meio a essa instabilidade dos tempos atuais, muitos indivíduos e grupos buscam retomar um equilíbrio e assegurar uma identidade estável, recorrendo à religião. Mas, embora a religião tenha se desenvolvido, ao longo da história, dando contornos ao corpo social, ultimamente as antigas instituições religiosas têm se enfraquecido, perdendo adeptos e não se apresentando mais tão atraentes para as pessoas. Em contrapartida, surgem e se disseminam, por toda parte, novas igrejas e novos grupos religiosos, com posturas acentuadamente totalitárias e fanáticas. Aqueles que se sentem desgarrados, excluídos ou ofendidos na vida social buscam então um sistema mais seguro que lhes forneça um ideal a realizar, uma causa para defender, um projeto para sustentar. Buscam a introdução em um nós, formar uma cultura, alicerçarem-se numa certeza e, se preciso for, até se sacrificarem por ela. Em meio a um mundo vertiginoso, e diante de uma realidade dura de ser encarada, vislumbra-se uma salvação numa paranoia partilhada, num delírio de massa. Freud (1930/2006) mesmo escreveu que uma das formas de lidar com os aspectos insuportáveis da realidade é remodelando-a de modo delirante. Com esse remodelamento do mundo, busca-se uma certeza de felicidade e uma proteção contra o sofrimento. Quando esse artifício é buscado conjuntamente por um grupo de pessoas, tem-se então um delírio de massa. Para Freud (1930/2006, p. 89), “as religiões da humanidade devem ser classificadas entre os delírios de massa desse tipo". Nesse contexto de instabilidades, explica Enriquez (2001), a religião buscada é, frequentemente, uma religião absolutista. Aquela que define claramente os ideais a seguir, os inimigos a combater e os irmãos aos quais se aliar, forjando, dessa forma, uma identidade coletiva maciça. Assim se forma uma comunidade que se deixa levar pelo equívoco da unidade-identidade.

No meio dessa unidade-identidade, o indivíduo desaparece. Se a identidade do 
indivíduo passa a ser definida, veementemente, como membro de um determinado grupo, essa identidade coletiva absorve a identidade pessoal e real: a singularidade é tragada pela massificação. Ao se tornar uniforme em relação aos outros e se igualar a eles, “[...] um indivíduo abandona sua distintividade num grupo $\mathrm{e}$ permite que seus outros membros o influenciem por sugestão, isso nos dá a impressão de que o faz por sentir necessidade de estar em harmonia com eles, de preferência a estar em oposição a eles [...]" (Freud, 1921/2006, p. 103). Isso leva a perceber que o principal fenômeno da Psicologia de grupo é a falta de liberdade do indivíduo dentro da formação grupal.

A absorção do indivíduo em um todo, quando a diferença é repelida, pode dar margem às condutas grupais megalomaníacas e fanáticas. Essas condutas tendem a absolutizar os ideais do grupo e, com isso, diluem-se as contradições do eu ideal e os limites do ideal do eu de cada indivíduo. Dessa forma, suas feridas narcísicas são atenuadas. Essa alteração no estado psíquico dos indivíduos, inseridos num grupo, pode ter uma explicação no mecanismo da sugestão, ao qual Freud se referiu em Psicologia de grupo e análise do ego. Nesse texto, ele propõe que “[...] os grupos se distinguem por sua especial sugestionabilidade", que consiste num "fenômeno irredutível e primitivo, um fato fundamental na vida mental do homem" (Freud, $1921 / 2006$, p. 100). Quando reunidos em grupo, uma "influência sem fundamento lógico e adequado se realiza" (Freud, 1921/2006, p. 101) entre os indivíduos. Por isso, Freud (1921/2006, p. 99) considera que "existe algo em nós que, quando nos damos conta de sinais de emoção em alguém mais, tende a fazer-nos cair na mesma emoção”.

A sugestionabilidade em um grupo, no entanto, é fundamentada por relações amorosas que "constituem a essência da mente grupal". O grupo, para Freud, "é claramente mantido por um poder de alguma espécie", isto é, por Eros, ou pulsão de vida, que "mantém unido tudo o que existe no mundo" (Freud, 1921/2006, p. 102).

Para Freud (1930/2006, p. 118), “é sempre possível unir um considerável número de pessoas no amor, enquanto sobrarem outras pessoas para receberem as manifestações de sua agressividade". Por isso, países rivalizam contra outros países, regiões contra outras, setores da sociedade contra seus diferentes, fenômeno possibilitado pelo narcisismo das pequenas diferenças. Em Moisés e o monoteísmo, ele explica que "a intolerância dos grupos é quase sempre, de modo bastante estranho, exibida mais intensamente contra pequenas diferenças do que contra diferenças fundamentais" (Freud, 1938/2006, p. 105). Dessa forma, esse narcisismo grupal configura-se, nas palavras de Freud (1930/2006, p. 119), como meio para uma “[...] satisfação conveniente e relativamente inócua da inclinação para a agressão, através da qual a coesão entre os membros da comunidade é tornada mais fácil”. Essa proposta parte do fato de que "não é fácil aos homens abandonar a satisfação da inclinação para a agressão”, o que gera certa necessidade de um grupo buscar pequenos motivos nos outros grupos, para tomá-los como "um escoadouro sob a forma de hostilidade contra intrusos" (Freud, 1930/2006, p. 118). 
Esse narcisismo das pequenas diferenças pode dar margem à xenofobia, ao racismo, aos preconceitos e às discriminações das mais variadas formas. Por isso, o ódio de um grupo para com os outros pode fomentar um delírio coletivo que aponta os estrangeiros, os dissidentes ou os desviantes como perseguidores onipotentes, ou seja, como seres de quem se tem que precaver e eliminar. É dessa forma que o ideal do fanatismo religioso se consolida com o objetivo de criar um mundo novo, onde será banido todo mal. Há uma fantasia de redenção e de salvação da sociedade (Enriquez, 2001), que está corrompida pelo mal e, por isso, deve ser liberta de todo poder satânico, identificado com os diferentes.

\section{As Relações entre o Fanatismo Religioso e o Poder}

Uma característica marcante dos grupos fanáticos religiosos atuais é sua busca de influência e tomada de poder na sociedade. Nessa ânsia pelo poder, revela-se a pulsão de morte como pulsão de domínio. Em O problema econômico do masoquismo, uma das formas com as quais Freud (1924/2006, p. 181) nomeia a pulsão de morte é pulsão de domínio ou vontade de poder: "O instinto [de morte] é então chamado de instinto destrutivo, instinto de domínio ou vontade de poder". Na busca pelo poder, toca-se numa dimensão marcante do fanatismo religioso contemporâneo: a dimensão política, vista no ímpeto fanático com que grupos religiosos defendem suas pautas, nas várias instâncias sociais. Bancadas de políticos, que levantam bandeiras de igrejas e de denominações religiosas, são sinais de que as exigências e lutas, permeadas por fanatismo, visam também a trazer proveito a alguns indivíduos e não só aos grupos religiosos que representam. Quando se assiste ao retorno de um religioso absolutista no meio social hodierno, esse retorno não é um simples sinal de autêntica renovação religiosa, mas talvez de verdadeira degeneração da religião, que mais uma vez se torna instrumento de manipulação e interesses políticos. Novamente, Estados, regiões do mundo e grupos sociais bem-definidos utilizam a fé para impor seu domínio e seu terror. Nesse sentido, é interessante observar que, quando Freud $(1938 / 2006)$ se referiu ao processo de desenvolvimento do monoteísmo, ele acenou para o aspecto político dessa configuração religiosa que, no fundo, foi também uma busca de imposição de um poder monolítico sobre a diversidade de povos e culturas diferentes: "No Egito, até onde podemos compreender, o monoteísmo cresceu como um subproduto do imperialismo. Deus era um reflexo do faraó, que era soberano absoluto de um grande império mundial" (Freud, 1938/2006, p. 78). Noutra passagem, Freud (1938/2006, p. 122) diz que, “no caso da gênese do monoteísmo, contudo, não podemos apontar para fator externo, exceto o que já mencionamos - que esse desenvolvimento esteve vinculado ao estabelecimento de relações mais estreitas entre nações diferentes e à construção de um grande império".

O fanatismo religioso sem o vínculo com interesses políticos não passa de um fenômeno de seitas isoladas no meio social, fechadas sobre si mesmas, cientes de seu direito de existir e constituindo parte do folclore de uma nação (Enriquez, 2001). Mas, quando 
atrelado a jogos de interesses políticos, o ideal fanático se agiganta e chega a pretensões de domínio para além do próprio âmbito religioso. Se um dos princípios do Estado laico é a separação entre as Igrejas e o Estado, as atuais ingerências dos meios religiosos, sobretudo dos mais intransigentes, em assuntos de ordem política e social e a infiltração de líderes religiosos nas diversas instâncias do governo das nações, mostram que a pretendida separação é aparente ou já não existe mais. O próprio Estado laico frequentemente faz apelo às competências religiosas e se mostra sensível a seus pontos de vista. O retorno da religião, em sua forma intransigente e dominadora, tal qual se expressa no fanatismo, traz consigo uma latente ambiguidade: não se trata simplesmente de uma afirmação da necessidade da transcendência, mas de novo meio de dominação política que se serve de aparatos religiosos. Isso demonstra que o fanatismo religioso se alimenta dos descaminhos e da corrupção na sociedade.

\section{Considerações Finais}

Em relação a crenças, não existe quem que não as tenha. Todo ser humano crê, de alguma maneira, em algo, mesmo que seja avesso a instituições religiosas e mesmo que aquilo em que acredita não se vincule a dogmas de religiões instituídas. Todos têm seus valores nos quais se inspiram e dos quais se servem para se direcionarem na vida. Não é possível decidir racionalmente quais valores são mais convenientes e quais são menos convenientes para além do próprio sujeito que neles se firma. Por isso, os valores religiosos também podem ser respeitados como quaisquer outros. Respeitá- los, porém, não significa, necessariamente, darlhes o estatuto de verdades absolutas, que devem ser aceitas igualmente por todos, pois, desse modo, tornam-se instrumentos a serviço da dominação e manipulação das consciências alheias.

Por outro lado, quando o sentido do religioso está imiscuído com interesses políticos, quando os valores religiosos são apresentados como pretensões ideológicas que impedem a liberdade de pensar e negam a legitimidade da pluralidade de cosmovisões na sociedade, quando um grupo ou uma sociedade seguem os caminhos de uma entropia que também leva seus membros a se fecharem, desaparece a reflexão. A perversão e a paranoia parecem triunfar e a pulsão de morte lança seus domínios no campo do sagrado e da sociedade.

A tentação do totalitarismo pode se fazer presente no campo da religião, da política, da academia ou de qualquer sistema ideológico. O desejo de homogeneizar o pensamento, ou de matá-lo quando persiste na diferença, vez ou outra desponta nos variados fenômenos sociais, como acontece frequentemente nos movimentos religiosos intolerantes.

O levante do fanatismo religioso, na atualidade, parece indicar que a tendência totalitária continua uma ameaça à necessária liberdade no convívio social, sem a qual se torna impossível garantir o direito de cidadania às diferentes visões de mundo e estilos de vida. Essa situação demonstra o quanto é urgente abrir caminhos para uma reflexão que busque identificar onde e como atua essa tendência mortífera, a fim de não sucumbir ao seu domínio. 


\section{Referências}

Bobbio, N., Matteucci, N., \&Pasquino, G. (1998). Dicionário de Politica (C. C. Varriale et al., Trad.). Brasília: Editora da Universidade de Brasília.

Bonome, J. R. (2009). Fundamentalismo religioso e terrorismo político. Goiânia: Editora da Universidade Católica de Goiás

Efésios. (2002). In Bíblia: Tradução ecumênica. São Paulo: Edições Loyola.

Enriquez, E. (2001). O fanatismo religioso e político. In E. Enriquez, J. Dubost, A. Lévy \& A. Nicolaï (Orgs.). Psicossociologia: análise social e intervenção (pp. 75-89, M. N. da M. Machado, Trad.). Belo Horizonte: Autêntica.

Êxodo. (2002). In Bíblia: Tradução ecumênica. São Paulo: Edições Loyola.

Freud, S. (2006). Totem e tabu (Vol. 13, J. Salomão, Trad.). Rio de Janeiro: Imago. (Trabalho original publicado em 1913).

Freud, S. (2006). Psicologia de grupo e análise do ego (Vol. 18, J. Salomão, Trad.). Rio de Janeiro: Imago. (Trabalho original publicado em 1921).

Freud, S. (2006). O problema econômico do masoquismo (Vol. 19, J. Salomão, Trad.). Rio de Janeiro: Imago. (Trabalho original publicado em 1924).

Freud, S. (2006). O Mal estar na civilizaçãa (Vol. 21, J. Salomão, Trad.). Rio de Janeiro: Imago. (Trabalho original publicado em 1930).

Freud, S. (2006). Moisés e o monoteísmo (Vol. 23, J. Salomão, Trad.). Rio de Janeiro: Imago. (Trabalho original publicado em 1938).

Mellor, S. M. (2004). Sobre a necessidade de crer (P. Fernandes \& L. Sarmatz, Trad.). São Paulo: Unimarco.

Neto, F. K., Rosário, A. B. (2016). O paradoxo religião e violência: Reflexões psicanalíticas. In J. O. Moreira, F. K., Neto \& A. B. Rosário (Orgs.). Violência(s): diálogos com a Psicanálise (pp. 117-125).

Curitiba: Editora CRV.

Onfray, M. (2007). Tratado de ateologia: física da metafísica (M. Sthael, Trad.). São Paulo: WMF Martins Fontes.

Oro, P. I. (1996). O outro é o demônio: uma análise sociológica do fundamentalismo. São Paulo: Paulus.

Ribeiro, M. (2011). O desafio da paz. Contribuição das/às religiões: Alguns elementos iniciais. Revista Atualidade Teológica, 39(15), 583-596.

Recebido em: 9/3/2018

Aprovado em: 27/8/2018 